\title{
Investigation of inflammation related gene polymorphism of the mannose-binding lectin 2 in schizophrenia and bipolar disorder
}

Hasan M. Aytac, MD, Menekse S. Yazar, MD, Ayse Erol, MSc, Sacide Pehlivan, PhD.

\begin{abstract}
الأهداف : دراسة العلاقة بين الكودون المرتبط بالمانوز 2 (MBL2)

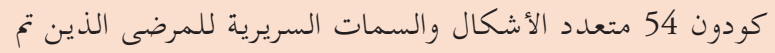
تشخيصهم بالفصام (SCZ) أو الاضطراب ثنائي القطب (BD)

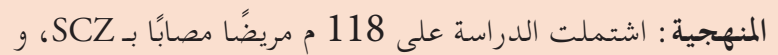

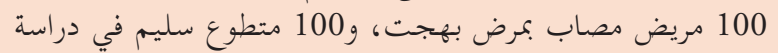

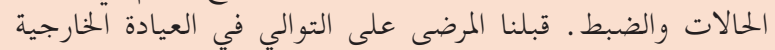

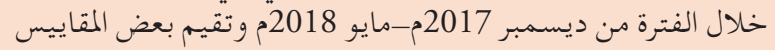

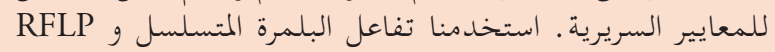

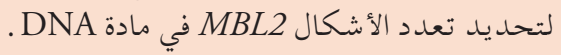

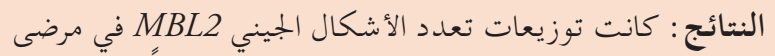

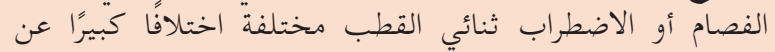

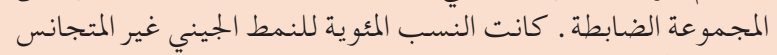

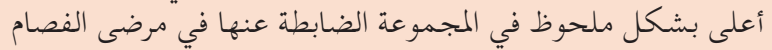

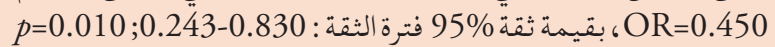
أو الاضطراب ثنائي القطب فترة الثقة في فترة

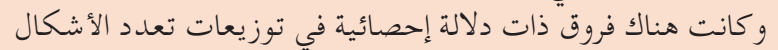

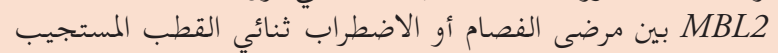

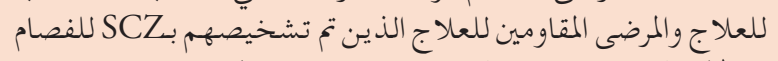

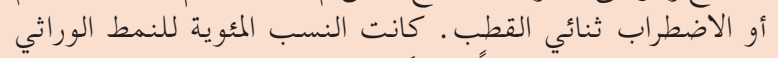

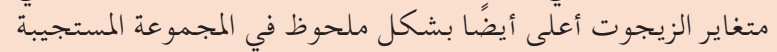

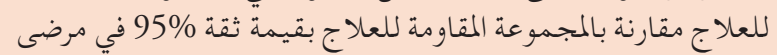
الفصام OR: 7.857; Cl: 1.006-61.363; ثنائي القطب OR: 8.782; Cl: 1.114-69.197;

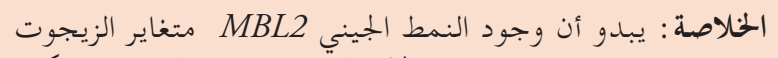

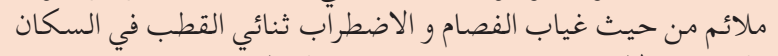

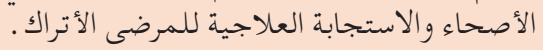

Objectives: To investigate the association between mannose-binding lectin 2 (MBL2) codon 54 polymorphism and clinical features of patients diagnosed with schizophrenia (SCZ) or bipolar disorder (BD).
Methods: One hundred and eighteen patients with SCZ, 100 patients with BD, and 100 healthy volunteers were included in the case-control study. The patients consecutively admitted to the outpatient clinic in December 2017-May 2018 and were evaluated with some scales for clinical parameters. Polymerase chain reaction and RFLP were used to determine $M B L 2$ polymorphism in DNA material.

Results: The $M B L 2$ gene polymorphism distributions in SCZ or BD patients were significantly different from the control group. The heterozygous genotype percentages were significantly higher in the control group than in the SCZ or BD patients (OR: 0.450; 95\% Cl: $0.243-0.830 ; p=0.010$; OR: $0.532 ; 95 \% \mathrm{Cl}$ : $0.284-0.995 ; p=0.047$, respectively), and there were statistically significant differences in the MBL2 polymorphism distributions between treatmentresponsive $S C Z$ or $B D$ patients and treatment-resistant patients diagnosed with $\mathrm{SCZ}$ or $\mathrm{BD}$. The heterozygous genotype percentages were also significantly higher in the treatment-responsive group than in the treatmentresistant group in SCZ or BD patients (OR: 7.857; 95\% Cl: $1.006-61.363 ; p=0.023$; OR: $8.782 ; 95 \%$ Cl: 1.114-69.197; $p=0.016$, respectively).

Conclusion: The presence of a heterozygous MBL2 genotype seems to be favorable both in terms of the absence of SCZ and BD in the healthy population and treatment response for Turkish patients.

Neurosciences 2021; Vol. 26 (4): 346-356 doi: $10.17712 / n s j .2021 .4 .20200050$

From the Department of Psychiatry (Aytac), Basaksehir Cam and Sakura City Hospital, from the Department of Psychiatry (Yazar), the Bakirkoy Research and Training Hospital for Psychiatry, Neurology and Neurosurgery; from the Department of Medical Biology (Erol, Pehlivan), Istanbul Faculty of Medicine, Istanbul University, Istanbul, Turkey.

Received 30th March 2021. Accepted 18th July 2021.

Address correspondence and reprint request to: Dr. Hasan M. Aytac, Department of Psychiatry, Basaksehir Cam and Sakura City Hospital, Istanbul, Turkey.E-mail: hasanmervan.aytac@saglik.gov.tr ORCID ID: https://orcid.org/0000-0002-1053-6808 
Chizophrenia (SCZ) and bipolar disorder (BD) $\checkmark$ are chronic psychiatric disorders that cause substantial disruptions in psychosocial capacity and occur in approximately $1 \%$ of the world population. ${ }^{1}$ Genome-wide association studies (GWAS) of Psychiatric Genomics Consortium for SCZ recognized more than a hundred common single nucleotide polymorphisms (SNPs) with minor individual effects presenting susceptibility to the SCZ. ${ }^{2}$ A similar mega-analysis for $\mathrm{BD}$, although including a more moderate sample, identified common risk variants specific to BD. ${ }^{3}$ The long-lasting alterations in gene expression patterns after environmental exposures imply that epigenetic mechanisms might also play a critical role in chronic psychiatric disorders. ${ }^{4}$ Again, previous researches have constantly reported shared genetic etiology between $\mathrm{SCZ}$ and BD. Researches showing the genetic overlap between SCZ and BD have improved from studying family and twin inheritance to determine genetic correlation and performing polygenic risk score analysis from GWAS data in large case-control samples. ${ }^{5}$ Despite these researches with large sample size, the cause of both disorders is still relatively unknown; recent studies have shown that uncontrolled activity of microglia and excessive inflammatory responses caused by pro-inflammatory cytokines are among the factors that play a role in the development of SCZ and $\mathrm{BD}$ based on genetic susceptibility. ${ }^{1,6} \mathrm{~A}$ relationship between SCZ and many autoimmune diseases and an increase in the prevalence of an autoimmune disease occurrence by about $45 \%$ have been found. Moreover, infections of embryonic and early childhood periods lead to delays in fetal brain development and excessive synaptic pruning during adolescence, are among the possible risk factors of psychosis. ${ }^{78}$ Systemic inflammation and central inflammation are thought to be associated with episodes, remission, and prognosis of BD. Neuroendocrine irregularities, neurotransmitter abnormalities, and glial cell dysfunctions cause plastic alterations in the mood-regulating brain areas. The high rate of comorbid autoimmune diseases also supports this claim. ${ }^{9}$

Disclosure. The authors declare no conflict of interests, and the work was not supported or funded by any drug company. This research extracted from a thesis of specialization in psychiatry (Thesis No: 561185), and the authors received no specific funding for this research.
Mannose-binding lectin (MBL) has a vital function in the innate immune system by stimulating the complement system's lectin pathway. Therefore, it is the only collectin that binds to microorganisms, serves as an opsonin, promotes phagocytosis, and stimulates macrophages. MBL2 gene, which consists of 4 exons in the q11.2-q21 region of the long arm of chromosome 10, encoded MBL. Mutation at codon 54 follows in a replacement of glycine to aspartic acid (allele B), and the normal MBL2 allele is defined by allele A. ${ }^{10-12}$ In heterozygous mutants, serum $\mathrm{MBL}$ decreases almost 10 -fold, whereas, in homozygous mutants, the level decreases to an undetectable level. MBL deficiency is the most common immune defect in humans, affecting approximately $5-7 \%$ of individuals. ${ }^{13} \mathrm{~A}$ decrease in serum MBL level can cause recurrent spontaneous miscarriage, ${ }^{14}$ premature birth, ${ }^{15}$ and exacerbation of chronic diseases such as ischemic heart disease, ${ }^{16}$ and severe infections such as sepsis and systemic inflammatory response syndrome (SIRS). ${ }^{17}$ Besides, previous studies suggested that MBL plays an essential role in the pathogenesis of autoimmune diseases. ${ }^{12,18} \mathrm{We}$ believe that this is the first case-control study comparing MBL2 genotype distributions in patients with SCZ or $\mathrm{BD}$ according to treatment resistance, clinical characteristics, and scale scores in detail.

Aims of the study. We aimed to examine whether $M B L 2$ codon 54 polymorphism was involved in the etiopathogenesis and treatment response of SCZ and $\mathrm{BD}$ compared with healthy controls.

Methods. Patient selection. The patients diagnosed with SCZ $(n=118)$ or BD $(n=100)$ were consecutively admitted to the outpatient clinic of the Bakirkoy Mazhar Osman Mental Health and Neurology Training and Research Hospital in December 2017-May 2018 for 6 months; additionally, 100 gender-, age- and ethnicitymatched healthy participants were included in our casecontrol study. This study was according to the ethical standards on human experimentation confirmed by the Helsinki Declaration and approved by the Clinical Research Ethics Committee of the Istanbul Faculty of Medicine (21/21.12.2017). ${ }^{19}$

Diagnoses and symptom measurement. We instructed the participants concerning the study's aim, materials, and methods and acquired their written informed consent. In addition, we applied the researchers' detailed interview data form about clinical information. Then, the Structured Clinical Interview for DSM-IV Axis-I Disorders (SCID-I) was administered to verify the patients' diagnosis. ${ }^{20,21}$ The Positive and Negative 
Table 1 - The clinical characteristics of patients.

\begin{tabular}{lcc}
\hline Characteristics & $\begin{array}{c}\text { Schizophrenia } \\
\mathbf{n}=118\end{array}$ & $\begin{array}{c}\text { Bipolar disorder } \\
\mathbf{n}=100\end{array}$ \\
\hline $\begin{array}{l}\text { Gender } \\
\text { Female }\end{array}$ & $31(26.3)$ & $58(58)$ \\
Male & $87(73.7)$ & $42(42)$ \\
Treatment resistance & & \\
No & $92(77.9)$ & $76(76)$ \\
Yes & $26(22.1)$ & $24(24)$ \\
MBL2 & & \\
AA & $87(73.7)$ & $73(73)$ \\
AB & $23(19.5)$ & $22(22)$ \\
BB & $8(6.8)$ & $5(5)$ \\
& Median & Median \\
\multicolumn{2}{c}{ (min-max) } \\
Age & $41(22-64)$ & $40.5(19-64)$ \\
Age of onset (year) & $22(5-60)$ & $24(10-52)$ \\
Duration of dis. (year) & $15.5(1-45)$ & $15(0.5-40)$ \\
Number of Hospt. & $2(0-30)$ & $2(0-21)$ \\
Last Hospt. (years ago) & $4(0.1-45)$ & $2(0.1-38)$ \\
\hline \multicolumn{2}{c}{ min - minimum, max - maximum, dis - disease, hospt- } \\
hospitalization
\end{tabular}

Table 2 - The scale scores of patients.

\begin{tabular}{lc}
\hline Schizophrenia & Median(min-max) \\
\hline PANSS pos. & $11(7-24)$ \\
PANSS neg. & $16(7-33)$ \\
PANSS psycho. & $30(17-54)$ \\
PANSS total & $58(33-102)$ \\
SATCI & $14(0-18)$ \\
CGI sev. & $5(3-7)$ \\
CGI imp. & $2(1-4)$ \\
Bipolar Disorder & Median(min-max) \\
Manic episode & $2(0-25)$ \\
Dep. episode & $1(0-12)$ \\
Total episode & $4(1-27)$ \\
HAM-D & $9(0-34)$ \\
YMRS & $6(0-38)$ \\
CGI sev. & $5(2-7)$ \\
CGI imp. & $2(1-4)$ \\
\hline \multicolumn{2}{c}{ min - minimum, max - maximum, PANSS - positive and } \\
negative syndrome scale, SATCI - schedule for assessing the \\
three components of insight, CGI - clinical global impression \\
scale, HAM-D - hamilton depression rating scale, YMRS - \\
young mania rating scale, pos - positive, neg - negative, psycho \\
- psychopathology, sev - severity, imp - improvement, dep - \\
depressive, hist - history, cyc - cycling, postpart - postpartum \\
\hline
\end{tabular}

Table 3 - Comparison of $M B L 2$ genotype distribution of patients with the control group.

\begin{tabular}{|c|c|c|c|c|c|}
\hline Genotype & Schizophrenia & Control & OR & $95 \% \mathrm{CI}$ & $P$-value \\
\hline$M B L 2$ & $\mathrm{n}={ }^{\mathrm{a}}(\%)$ & $\mathrm{n}=100(\%)$ & & & \\
\hline $\mathrm{AA}$ & $87(73.7)$ & $64(64)$ & $1.579^{*}$ & $0.885-2.816^{*}$ & $0.121^{*}$ \\
\hline $\mathrm{AB}$ & $23(19.5)$ & $35(35)$ & $0.450^{*}$ & $0.243-0.830^{*}$ & $0.010^{*}$ \\
\hline $\mathrm{BB}$ & $8(6.8)$ & $1(1)$ & $1.689^{8}$ & $1.297-2.200^{8}$ & $0.041^{8 x}$ \\
\hline \multicolumn{6}{|l|}{ Allele } \\
\hline A & $197(83.5)$ & $163(81.5)$ & & & \\
\hline B & $39(16.5)$ & 37 (18.5) & $1.147^{\&}$ & $0.699-1.882^{\&}$ & $0.588^{\&}$ \\
\hline \multicolumn{6}{|c|}{ Bipolar Dis. } \\
\hline$M B L 2$ & $\mathrm{n}={ }^{\mathrm{b}}(\%)$ & $\mathrm{n}=100(\%)$ & & & \\
\hline $\mathrm{AA}$ & $73(73)$ & $64(64)$ & $1.521^{*}$ & $0.834-2.775^{*}$ & $0.171^{*}$ \\
\hline $\mathrm{AB}$ & $22(22)$ & $35(35)$ & $0.532^{*}$ & $0.284-0.995^{*}$ & $0.047^{*}$ \\
\hline $\mathrm{BB}$ & $5(5)$ & $1(1)$ & $5.211^{\&}$ & $0.598-45.426^{8}$ & $0.212^{\& x}$ \\
\hline \multicolumn{6}{|l|}{ Allele } \\
\hline A & $168(84)$ & $163(81.5)$ & & & \\
\hline $\mathrm{B}$ & $32(16)$ & 37 (18.5) & $1.192^{*}$ & $0.709-2.004^{*}$ & $0.508^{*}$ \\
\hline
\end{tabular}

Symptoms Scale (PANSS) ${ }^{22,23}$ was applied for patients with SCZ, while the Hamilton Depression Rating Scale (HAM-D $)^{24,25}$ and the Young Mania Rating Scale ${ }^{26,27}$ were for evaluating BD patients concerning the severity of symptoms. We assessed the impairment of insight in SCZ with the Schedule for Assessing the Three Components of Insight (SATCI) ${ }^{28,29}$ Finally, we investigated the severity and treatment response of the psychiatric disorder with the Clinical Global Impression Scale (CGI)..$^{30}$ 
Table 4 - Comparison of $M B L 2$ genotype distributions of schizophrenia or bipolar disorder patients with the same gender control group.

\begin{tabular}{|c|c|c|c|c|c|}
\hline Genotype & Schizophrenia & Control & OR & $95 \% \mathrm{CI}$ & $P$-value \\
\hline Male & $\mathrm{n}={ }^{\mathrm{a}}(\%)$ & $\mathrm{n}=46(\%)$ & & & \\
\hline $\mathrm{AA}$ & $68(78.2)$ & $31(67.4)$ & $1.732^{*}$ & $0.779-3.851^{*}$ & $0.176^{*}$ \\
\hline $\mathrm{AB}$ & $17(19.5)$ & 15 (32.6) & $0.450^{*}$ & $0.243-0.830^{*}$ & $0.094^{*}$ \\
\hline $\mathrm{BB}$ & $2(2.3)$ & $0(0)$ & $1.541^{8 x}$ & $1.359-1.748^{8}$ & $0.544^{8 x}$ \\
\hline \multicolumn{6}{|l|}{ Allele } \\
\hline A & $153(87.9)$ & 77 (83.3) & & & \\
\hline B & $21(12.1)$ & $15(16.7)$ & $1.419^{*}$ & $0.693-2.907^{*}$ & $0.337^{*}$ \\
\hline Female & $\mathrm{n}=\mathrm{b}(\%)$ & $\mathrm{n}=54(\%)$ & & & \\
\hline $\mathrm{AA}$ & $19(61.3)$ & 33 (61.1) & $1.008^{*}$ & $0.407-2.494^{*}$ & $0.987^{*}$ \\
\hline $\mathrm{AB}$ & $6(19.4)$ & $20(37)$ & $0.408^{*}$ & $0.143-1.164^{*}$ & $0.089^{*}$ \\
\hline $\mathrm{BB}$ & $6(19.4)$ & $1(1.9)$ & $12.720^{8 x}$ & $1.453-111.378^{8}$ & $0.009^{8}$ \\
\hline \multicolumn{6}{|l|}{ Allele } \\
\hline A & $44(71)$ & $86(79.6)$ & & & \\
\hline B & $18(29)$ & $22(20.4)$ & $0.625^{*}$ & $0.304-1.286^{*}$ & $0.200^{*}$ \\
\hline \multicolumn{6}{|c|}{ Bipolar Dis. } \\
\hline Male & $\mathrm{n}=\mathrm{c}(\%)$ & $\mathrm{n}=46(\%)$ & & & \\
\hline $\mathrm{AA}$ & $31(73.8)$ & $31(67.4)$ & $1.364^{*}$ & $0.541-3.434^{*}$ & $0.510^{*}$ \\
\hline $\mathrm{AB}$ & $8(19)$ & 15 (32.6) & $0.486^{*}$ & $0.181-1.304^{*}$ & $0.148^{*}$ \\
\hline $\mathrm{BB}$ & $3(7.1)$ & $0(0)$ & $2.179^{8}$ & $1.730-2.746^{8}$ & $0.105^{8}$ \\
\hline \multicolumn{6}{|l|}{ Allele } \\
\hline A & $70(83.3)$ & $77(83.3)$ & & & \\
\hline B & $14(16.7)$ & $15(16.7)$ & $0.974^{\&}$ & $0.439-2.161^{\&}$ & $0.948^{8 x}$ \\
\hline Female & $\mathrm{n}={ }^{\mathrm{d}}(\%)$ & $\mathrm{n}=54(\%)$ & & & \\
\hline $\mathrm{AA}$ & $42(72.4)$ & $33(61.1)$ & $1.670^{*}$ & $0.755-3.696^{*}$ & $0.204^{*}$ \\
\hline $\mathrm{AB}$ & $14(24.1)$ & $20(37)$ & $0.541^{*}$ & $0.239-1.224^{*}$ & $0.138^{*}$ \\
\hline $\mathrm{BB}$ & $2(3.4)$ & $1(1.9)$ & $1.893^{8}$ & $0.167-21.494^{8}$ & $1.000^{\&}$ \\
\hline \multicolumn{6}{|l|}{ Allele } \\
\hline A & $98(84.5)$ & $86(79.6)$ & & & \\
\hline $\mathrm{B}$ & $18(15.5)$ & $22(20.4)$ & $1.393^{*}$ & $0.701-2.768^{*}$ & $0.343^{*}$ \\
\hline
\end{tabular}

Criteria for treatment-resistant in schizophrenia and bipolar disorder. Conley and Kelly's criteria ${ }^{31}$ were applied to define the resistance of treatment in SCZ patients. It was described as a lack of response to treatment and the permanence of moderate to severe symptoms despite 2 separate antipsychotics in the proper dose (400-600 $\mathrm{mg} /$ day chlorpromazine) and duration (4-6 weeks). ${ }^{32}$ For treatment resistance in BD, Sachs suggested that mood episodes must be handled separately and defined the resistance as being no improvement in the mania for 6 weeks despite using at least 2 antimanic drugs with adequate dose and duration of treatment (provided that no drug caused an increase in the mood). Additionally, depression symptoms continued despite 2 different antidepressants (each for 6 weeks). The maintenance phase is indicated as 6 months for mood episodes (provided that no drug caused an increase in the mood). ${ }^{33,34}$

Inclusion and exclusion criteria: Participants of either gender, literate, of 18 to 65 years of age, agreed to be involved in the study, diagnosed with SCZ or BD according to the SCID-I interview, had no other systemic/neurological disease that may affect cognitive functions (dementia, epilepsy, Parkinson disease, head trauma accompanied by loss of consciousness) included in the study. In addition, we had excluded subjects who refused participation or had mental retardation, neurodevelopmental disorders, a diagnosis of axis-1 disorder other than SCZ or BD due to SCID-I interview, SCZ, or BD secondary to a general medical condition. 
Table 5 - Comparison of $M B L 2$ genotype distributions of patients due to the resistance to treatment and clinical specifiers.

\begin{tabular}{|c|c|c|c|c|c|}
\hline & No & Yes & OR & $95 \% \mathrm{CI}$ & $P$-value \\
\hline \multicolumn{6}{|c|}{ Treatment Resist. } \\
\hline \multicolumn{6}{|c|}{ Schizophrenia } \\
\hline$M B L 2$ & $\mathrm{n}={ }^{\mathrm{a}}(\%)$ & $\mathrm{n}=26(\%)$ & & & \\
\hline $\mathrm{AA}$ & $66(71.7)$ & $21(80.8)$ & $0.604^{*}$ & $0.206-1.772^{*}$ & $0.356^{*}$ \\
\hline $\mathrm{AB}$ & $22(23.9)$ & $1(3.8)$ & $7.857^{*}$ & $1.006-61.363^{*}$ & $0.023^{*}$ \\
\hline $\mathrm{BB}$ & $4(4.4)$ & $4(14.8)$ & $0.284^{8 x}$ & $0.066-1.218^{8 x}$ & $0.093^{8}$ \\
\hline \multicolumn{6}{|l|}{ Allele } \\
\hline A & $154(84.1)$ & $43(81.5)$ & & & \\
\hline $\mathrm{B}$ & $30(15.9)$ & $9(18.5)$ & $1.074^{*}$ & $0.474-2.435^{*}$ & $0.863^{*}$ \\
\hline \multicolumn{6}{|c|}{ Bipolar Dis. } \\
\hline$M B L 2$ & $\mathrm{n}={ }^{\mathrm{b}}(\%)$ & $\mathrm{n}=24(\%)$ & & & \\
\hline $\mathrm{AA}$ & $51(67.1)$ & $22(91.7)$ & $0.185^{*}$ & $0.040-0.852^{*}$ & $0.018^{*}$ \\
\hline $\mathrm{AB}$ & $21(27.6)$ & $1(4.2)$ & $8.782^{*}$ & $1.114-69.197^{*}$ & $0.016^{*}$ \\
\hline $\mathrm{BB}$ & $4(5.3)$ & $1(4.2)$ & $1.278^{\&}$ & $0.136-12.015^{8}$ & $1.000^{8}$ \\
\hline \multicolumn{6}{|l|}{ Allele } \\
\hline A & $123(80.9)$ & $45(93.8)$ & & & \\
\hline $\mathrm{B}$ & $29(19.1)$ & $3(6.3)$ & $0.283^{*}$ & $0.082-0.974^{*}$ & $0.035^{*}$ \\
\hline \multicolumn{6}{|c|}{ Atypical Depres./ Bipolar Dis. } \\
\hline$M B L 2$ & $\mathrm{n}=\mathrm{c}^{\mathrm{c}}(\%)$ & $\mathrm{n}=20(\%)$ & & & \\
\hline $\mathrm{AA}$ & $55(68.8)$ & $18(90)$ & $0.244^{*}$ & $0.053-1.135^{*}$ & $0.056^{*}$ \\
\hline $\mathrm{AB}$ & $20(25)$ & $2(10)$ & $3.000^{8}$ & $0.639-14.079^{8}$ & $0.228^{8}$ \\
\hline $\mathrm{BB}$ & $5(6.3)$ & $0(0)$ & $1.267^{8}$ & $1.142-1.405^{8}$ & $0.580^{2}$ \\
\hline \multicolumn{6}{|l|}{ Allele } \\
\hline A & $130(81.2)$ & $38(95)$ & & & \\
\hline $\mathrm{B}$ & $30(18.8)$ & $2(5)$ & $0.228^{*}$ & $0.052-0.998^{*}$ & $0.034^{*}$ \\
\hline \multicolumn{6}{|c|}{$\begin{array}{c}{ }^{a} n=92,{ }^{b} n=76,{ }^{c} n=80, \text { Resist-Resistance, OR- odds ratio, CI - confidence } \\
\text { interval, Depres - depression, *Pearson chi-square, }{ }^{*} \text { Fisher's exact test, Dis - } \\
\text { disorder }\end{array}$} \\
\hline
\end{tabular}

DNA isolation and genotyping analyses. We used the polymerase chain reaction (PCR) and restriction fragment length polymorphism (RFLP) method to analyze the $M B L 2$ codon 54 polymorphism. ${ }^{35}$ Therefore a three-step pathway was used to detect gene polymorphisms as genomic DNA isolation, amplification of target gene region by PCR, restriction enzyme digestion, and application of agarose gel electrophoresis method for visualization of the obtained product. We collected 2 cc blood samples in ethylene diamine tetraacetic acid (EDTA) tubes to obtain DNA from participants. After the genomic DNA was isolated with the Plus Blood Genomic DNA Purification Kit (GeneMark), reproduction of the desired region of DNA was carried out by PCR using artificially prepared oligonucleotide primers. For all these processes, the GeneAmp PCR System 9700 brand PCR device was used. At the end of the procedure, $10 \mu \mathrm{l}$ of the PCR product was removed, and electrophoresis was carried out using $2 \%$ agarose gel. DNA strands were stained with ethidium bromide and observed in ultraviolet light. The DNA allele cut by restriction enzyme was noted as A allele (Normal: 260+89 bp), and the non-cut DNA was noted as B allele (Mutant: 349 bp) (BanI restriction endonuclease enzyme from New England Biolabs). If the 349 bp PCR product from the MBL2 gene was cut into 2 different products of $260 \mathrm{bp}$ and $89 \mathrm{bp}$, then the genotype was identified as AA; if three specific products were formed as $349 \mathrm{bp}, 260 \mathrm{bp}$, and $89 \mathrm{bp}$, then the genotype was identified as $\mathrm{AB}$; and if the product was $349 \mathrm{bp}$, then the genotype was identified as BB.

Statistical analyses. The statistical analysis was performed using IBM SPSS version 21.0 (IBM Corp. released 2012; Armonk, NY, USA). Quantitative data (clinical characteristics and scale scores) represented as descriptive statistics included median, minimum, maximum values, and the associations between MBL genotype or alleles frequency distributions and clinical variables (gender, treatment response, and clinical specifiers) were analyzed by Fisher's exact test or Pearson 
Table 6 - Comparison of scale scores and clinical parameters according to MBL2 genotype in patients with bipolar disorder.

\begin{tabular}{|c|c|c|c|}
\hline & $\begin{array}{c}\text { AA } \\
\text { Median (min-max) }\end{array}$ & $\begin{array}{c}\mathrm{AB} / \mathrm{BB} \\
\text { Median (min-max) }\end{array}$ & ${ }^{* *} P$-value \\
\hline HAM-D score & $10(0-34)$ & $9(2-25)$ & 0.479 \\
\hline YMRS score & $4(0-38)$ & $7(0-28)$ & 0.207 \\
\hline $\begin{array}{l}\text { CGI } \\
\text { sev. }\end{array}$ & $5(2-7)$ & $5(3-7)$ & 0.698 \\
\hline $\begin{array}{l}\text { CGI } \\
\text { imp. }\end{array}$ & $2(1-4)$ & $2(1-4)$ & 0.847 \\
\hline $\begin{array}{l}\text { Manic } \\
\text { episode }\end{array}$ & $2(0-21)$ & $3(1-25)$ & 0.512 \\
\hline Dep. episode & $1(0-12)$ & $0(0-2)$ & 0.042 \\
\hline Total episode & $4(1-23)$ & $3(1-27)$ & 0.329 \\
\hline Duration of disease & $15(1-40)$ & $14(5-40)$ & 0.721 \\
\hline Age of onset & $24(13-44)$ & $25(10-52)$ & 0.457 \\
\hline Number of hospt. & $2(0-21)$ & $2(0-21)$ & 0.576 \\
\hline $\begin{array}{l}{ }^{* *} \text { Mann Whitne } \\
\text { impression scale, } \\
\text { rating scale, sev. - }\end{array}$ & $\begin{array}{l}\text { min - minimum, } \mathrm{n} \\
\mathrm{D} \text { - hamilton depre } \\
\text { imp - improvemen }\end{array}$ & $\begin{array}{l}\text { aximum, CGI - clin } \\
\text { ting scale, YMRS - } \\
\text { depressive; hospt - }\end{array}$ & $\begin{array}{l}\text { global } \\
\text { ng mania } \\
\text { italization }\end{array}$ \\
\hline
\end{tabular}

chi-square test. The allele and genotype frequencies determined according to Hardy-Weinberg equilibrium (HWE). The Shapiro-Wilk test of normality was carried out on continuous variables to verify the fit of the data to a normal distribution. Comparison of scale scores and clinical parameters according to the $M B L 2$ genotype were performed by Mann Whitney $U$ testing since the variables did not have a normal distribution. We had to group the genotypes by considering the presence of mutation allele $(\mathrm{AA}, \mathrm{AB} / \mathrm{BB})$ to compare scale scores of 2 groups containing a statistically significant number of patients. We accepted the statistical significance as $p<0.05$ for the outcomes of all analyses. The power analysis was performed with the "G*power" software (version 3.0.5, http://www.psycho.uni-duesseldorf.de/ abteilungen/aap/gpower3/), post hoc goodness of fit $\chi 2$ test, with an "-error" probability of 0.05 . The potential assumable impacts of population stratification bias in the studied population were estimated with the formulas of Lee and Wang, ${ }^{36}$ regarding MBL2 SNP frequencies at codon 54 reported for white populations, ${ }^{37-39}$ and incidence rates of BD and SCZ in Turkey, as reported by Erol et al. ${ }^{40}$

Results. MBL2 genotyping. 118 SCZ (31 female/ 87 male) and $100 \mathrm{BD}$ (58 female/ 42 male) patients were evaluated according to clinical characteristics and scale scores, as shown in Table 1 and Table 2. The MBL2 genotype distribution of SCZ was significantly different from the control group. The healthy control participants had a higher frequency of $M B L 2 \mathrm{AB}$ genotype than in the SCZ patients (OR: $0.450,95 \% \mathrm{Cl}: 0.243-0.830$; $p=0.010)$. In addition, the percentage of participants with the $\mathrm{BB}$ genotype was significantly higher in the SCZ group than in the control group (OR:1.689, 95\% $\mathrm{Cl}$ : $1.297-2.200 ; p=0.041)$. The $\mathrm{BD}$ group's $M B L 2$ genotype distribution was also significantly different from the control group. The $M B L 2 \mathrm{AB}$ genotype was significantly higher in the control group than the $\mathrm{BD}$ group (OR: $0.532 ; 95 \% \mathrm{Cl}: 0.284-0.995 ; p=0.047$ ) (Table 3). The MBL2 genotype distribution in the female SCZ group was significantly different from the female control group. The frequency of the $\mathrm{BB}$ genotype was significantly higher in female SCZ patients than in the same gender control group (OR: $12.720 ; 95 \% \mathrm{Cl}$ : $1.453-111.378 ; p=0.009)$. The $M B L 2$ genotype and the male or female BD group's allele frequency distributions were not significantly different from the same gender control group (Table 4).

Comparison of genotype distributions of patients based on the treatment resistance. The MBL2 genotype distribution was significantly different between the treatment-resistant and the treatment-responsive SCZ group. The frequency of the $\mathrm{AB}$ genotype was significantly higher in patients with treatmentresponsive SCZ than in patients with treatmentresistant SCZ (OR: 7.857; 95\%Cl: 1.006-61.363; $p=0.023$ ). While the frequency of the $\mathrm{AB}$ genotype was significantly higher in the treatment-responsive $\mathrm{BD}$ group compared to the treatment-resistance $\mathrm{BD}$ 
group (OR: 8.782; 95\%Cl: 1.114-69.197; $p=0.016$ ), the $M B L 2$ AA genotype was significantly higher in the treatment-resistance $\mathrm{BD}$ patient group than in the treatment-responsive BD group (OR: $0.185 ; 95 \% \mathrm{Cl}$ : $0.040-0.852 ; p=0.018)$. Also, the frequency of the A allele was significantly higher in the treatment-resistant $\mathrm{BD}$ patient group than in the treatment-responsive BD patient group (OR: 0.283; 95\%Cl: 0.082-0.974; $p=0.035)$ (Table 5).

Comparison of MBL2 genotype distributions of patients according to the presence of clinical specifiers. Comparing the MBL2 genotype and allele frequency distributions of the $\mathrm{BD}$ patients according to the presence of clinical specifiers (psychotic features, atypical features, seasonal pattern, mixed features, rapid cycling history, peripartum onset) showed that allele frequency distribution was significantly different between the groups of patients with $\mathrm{BD}$ in terms of atypical depression history. The frequency of the A allele was significantly higher in the group with a history of atypical depression (OR: 0.228; 95\% Cl: 0.052-0.998; $p=0.034$ ) (Table 5). However, there was no significant difference between the groups' other clinical specifiers (psychotic features, seasonal pattern, mixed features, rapid cycling history, peripartum onset) according to the $M B L 2$ genotype distributions ( $p>0.05$ ).

Comparison of age of onset, duration of disease, number of hospitalizations, and scale scores according to $M B L 2$ genotypes $(A A, A B / B B)$. When comparing the age of onset, duration of the disorder, a number of hospitalizations, and scale scores (SATCI, CGI sev., CGI imp., PANSS total, PANSS neg., PANSS pos., PANSS psycho.), regarding the $M B L 2$ genotype (AA, $\mathrm{AB} / \mathrm{BB}$ ) groups (grouping by considering the presence of mutation allele) in SCZ patients, there was not found a significant difference between groups of $M B L 2$ genotype $(p>0.05)$. However, comparing scale scores (CGI sev., CGI imp., HAM-D, YMRS) and clinical parameters (number of manic episodes, depressive episodes, total episodes, number of hospitalizations, age of onset, and duration of disorder) due to the MBL2 genotype $(\mathrm{AA}, \mathrm{AB} / \mathrm{BB})$ group in patients with $\mathrm{BD}$, the number of depressive episodes were significantly different between the groups of the MBL2 genotype $(p=0.042)$. The number of depressive episodes was significantly higher in patients with the AA genotype (Table 6).

Discussion. Our study analyzed data from 318 participants (118 SCZ, $100 \mathrm{BD}$ patients, and 100 healthy volunteers) and revealed that the participants carrying the $M B L 2 \mathrm{BB}$ genotype had a significantly higher risk of developing SCZ; the MBL2 AB genotype had a protective effect on the risk of SCZ. Mayilyan et al. found MBL-induced mannose-binding proteinassociated serine protease 2 (MASP-2) activity and, therefore, MBL and MASP-2-mediated complement activation capacity was higher level in SCZ patients than in the control group. ${ }^{41}$ They thought that the high activity of MASP-2-mediated complexes could promote extreme complement activation and excretion of inflammatory mediators by any activator. Again, in the SCZ patient group, the significantly higher rate of the homozygous genotype of the mutation allele (BB) than the control group was consistent with the literature. In a study by Foldager et $\mathrm{a}^{42}$ although the MBL concentration was high in the SCZ group, they showed that the genotype percentage with the mutation allele was higher in this group than in the healthy participants. Recently, we reported that $M B L 2$ polymorphism is related to attempted suicide in SCZ, and macrophage migration inhibitory factor (MIF) polymorphism is associated with attempted suicide in BD. ${ }^{43}$ Again, it was found that MIF -173 G/C polymorphism is related to the impairment of insight and age of illness onset in SCZ in another research of ours. ${ }^{44}$ When the complement proteins and SCZ association researches were reviewed, a recent study determined that as $\mathrm{C} 4$ complement protein expression increases, the risk of SCZ increases; thus, neuronmicroglia interactions through the complement system have a part in the pathogenesis of SCZ. ${ }^{45}$

Additionally, in our study, the MBL2 AB genotype had a protective effect on the risk of $\mathrm{BD}$, the participants carrying the $\mathrm{BB}$ genotype were non-significantly higher percentages in the $\mathrm{BD}$ group. Accordingly, we can speculate that the heterozygous advantage for $M B L 2$ gene polymorphism is reported in terms of the absence of SCZ and BD in the healthy Turkish population. Although, in the literature, few studies on this subject have examined the role of the lectin pathway of the complement system in $\mathrm{BD}$, a study by Foldager et $\mathrm{al}^{46}$ on the $M B L 2$ genotype of patients with $\mathrm{BD}$ reported that the genotype with mutation allele was higher in the BD group than the controls similar to our study. Therefore, it was reported that MASP-2 levels were lower in $\mathrm{BD}$ patients than in the healthy participants. Furthermore, in a study examining the peripheral blood concentrations of C3a, C5a, C5b-9 complement cascades in 30 patients diagnosed with $\mathrm{BD}$ for at least ten years, the blood concentration of all values was higher than healthy controls. ${ }^{47}$

In our study, the percentage of patients with the $M B L 2 \mathrm{BB}$ genotype was significantly higher in women 
with SCZ than in the same gender healthy participants. In the literature, recent gene polymorphism studies have shown that some dopaminergic genes (CatecholO-methyltransferase (COMT), monoamine oxidase (MAO)) have a gender-specific relationship with SCZ and symptom types. In a study examining the connection between negative symptoms and polymorphisms in the COMT gene in SCZ adults, it was found that the rt740603 and rs740603 (G) -rs4818 $(\mathrm{G})$ haplotypes of the COMT gene may be related to the negative symptoms of SCZ, especially in women. ${ }^{48}$ In our study, the significantly higher detection of BB genotype in codon 54 compared to the control group in female SCZ patients may reveal that inflammation may take part in women with SCZ. If other inflammationrelated gene polymorphisms supported our findings, SNPs associated with inflammation might suggest that inflammation has gender-specific effects in psychiatric disorders.

The SCZ patients carrying the MBL2 AB genotype had a significantly lower risk of treatment resistance in our study. Previous literature on inflammation-related genes has reported that the predominance of the human leukocyte antigen-A1 (HLA-A1) allele in treatmentresistant $\mathrm{SCZ}$ was distinctive from treatment-responsive SCZ, ${ }^{49}$ but another study reported no significant difference between the groups' HLA antigens. ${ }^{50}$ Another GWAS examining the response to a single antipsychotic found an association with the rhotekin 2 (RTKN2) gene, which may affect both the innate and adaptive immune response by regulating the nuclear factor kappa B (NF- $\mathrm{B}$ ) pathway. ${ }^{51}$ Again, our published recent research investigating the connection between the SCZ and inflammation-related gene polymorphism in tumor necrosis factor-alpha (TNF- $\alpha$ ) -238 G/A, -308 G/A have found that TNF- $\alpha-238 \mathrm{G} / \mathrm{A}$ polymorphism is associated with treatment resistance in SCZ patients. ${ }^{26}$

Our study also showed statistically significant differences in the MBL2 genotype and allele frequency distributions between the treatment-resistant and the treatment-responsive BD group. Our findings showed that while the percentage of patients with the $\mathrm{AB}$ genotype was higher in patients with treatmentresponsive $\mathrm{BD}$ than in the treatment-resistant $\mathrm{BD}$ group, the $\mathrm{BD}$ patients carrying the $\mathrm{AA}$ genotype or A allele had a significantly higher risk of treatment resistance. When we reviewed the linkage studies on the response to treatment, the inositol pathway, the circadian signaling system, the neurotransmitter system, and brain-derived neurotrophic factor (BDNF)-related gene polymorphisms have found to be associated with the mechanism of action of lithium. ${ }^{52,53}$ Although we did not find any publications in the literature regarding the relationship between inflammation-related gene polymorphism and treatment response, several studies in the literature provide evidence to support the antiinflammatory outcomes of mood stabilizers through several mechanisms. It was suggested that lithium decreases the synthesis of pro-inflammatory enzymes and molecules (interleukin-1 (IL-1), TNF- $\alpha$, prostaglandins (PG), nitric oxide (NO), inducible nitric oxide synthase (iNOS), cyclooxygenase-2 (COX-2), and phospholipase A2 (PLA2)) and regulates microglial activity during treatment. ${ }^{54}$ Similar to lithium, valproic acid also inhibits the synthesis of COX-1 and COX-2 in the rat brain and down-regulates the arachidonic acid signal cascade. ${ }^{55}$ Thus, valproate and other antiepileptic mood stabilizers (lamotrigine, topiramate, carbamazepine, and oxcarbazepine) were also found to reduce the synthesis of many cytokines in vitro. ${ }^{54}$ Although our study is the first in this field, it is not surprising that our study reported a significant difference between $M B L 2$ variants and treatment resistance in $\mathrm{BD}$ patients considering the above anti-inflammatory effects of mood stabilizers.

Comparison of MBL2 genotype distributions in the patient group diagnosed with $\mathrm{BD}$ according to scale scores and clinical chaacteristics revealed that the number of depressive episodes was significantly higher in patients with the AA genotype. In a clinical study of 22 chronic and 24 first-episode BD patients, a negative correlation was found between serum $\mathrm{C} 4$ complement levels and disease duration in $\mathrm{BD}$ patients, while no correlation was found between factor $\mathrm{B}$ and $s \mathrm{C} 5 \mathrm{~b}-9$ levels and duration of disease. YMRS scores showed a statistically significant relationship only with blood sC5b-9 levels, while no significant connection was shown between Montgomery and Asberg Depression Scale (MADRS) scores and any complement levels in serum. Nevertheless, any complement factor in serum was not related to age and the number of manicdepressive episodes. ${ }^{56}$ In another study conducted in patients with SCZ and BD, a comparison of gene expression and the effect to Global Assessment of Functioning (GAF), CGI, PANSS, YMRS, and Calgary Depression Scale for Schizophrenia (CDSS) scores showed that AKT serine/threonine kinase 1 (AKT1) and double-stranded RNA-specific endoribonuclease (DICER1) gene expression levels were higher in patients diagnosed with BD compared to healthy participants and patients with SCZ. However, no relationship was found between AKT1, DICER1 gene expression and scale scores, the severity of manic-depressive symptoms, and dysfunction in BD patients. It has been proposed that the expression of AKT1 and DICER1 gene, which 
play a critical role in many signaling pathways, might be more specifically related to manic properties. ${ }^{57}$ On the contrary to these 2 studies, neopterin levels caused by cellular immune system activation were reported to be higher in patients with major depressive episodes than those with a single depressive episode and the control group. ${ }^{58}$ Moylan et $\mathrm{al}^{59}$ showed that inflammation had an essential role in the chronicization of depression, increased susceptibility to subsequent episodes, and accelerated the disease's progressive course. Similar to our findings, changes in inflammatory markers were associated with the number of depressive episodes.

In the present study, when we compared the $M B L 2$ genotypes and allele frequency distributions of patients in the 2 groups regarding clinical specifiers, we found a significant difference between the groups of patients with $\mathrm{BD}$ in terms of their history of atypical depression. Previous literature has demonstrated a potential relationship between inflammation and atypical features of depression. Increased appetite is the only atypical feature related to both inflammatory and metabolic markers in the context of depressive episodes, and this symptom may be a vital characteristic of the immuno-metabolic model of depression. ${ }^{60}$ In one study, atypical features were associated with decreased IL-4 and increased IL-2, while in another study, IL-2 levels were observed to be lower in patients with atypical depression. In a study comparing atypical depression and melancholic type depression, although serum CRP, IL-6, and TNF- $\alpha$ levels were not significantly different between the groups, serum CRP level was increased in atypical depression compared with the control group. ${ }^{60-62}$

In our study, the higher percentage of B allele in the $\mathrm{BD}$ group without a history of atypical depression than the BD group with a history of atypical depression supports a relationship between an atypical feature and the increase of inflammation in the depressive episode.

Several limitations should be considered in our study. If we consider the multi-genetic nature of SCZ and BD and gene-gene interaction or biological pathways in the etiology, our study's first limitation is that it was about single inflammation-related $M B L 2$ gene polymorphism. The second limitation of the study was the small sample size, although it was calculated by considering the frequencies of $M B L 2$ polymorphism in the white population. Finally, only polymorphism in codon 54 was investigated, but it was impossible to determine whether other MBL2 mutations in codon 52 and codon 57 precipitated the disorder.

In conclusion, in our study, having the heterozygosity for $M B L 2$ can be advantageous for the response to treatment and the prevention of disease occurrence in both BD and SCZ patients. Especially in female patients with SCZ, there may be evidence that inflammation may play a role in the disease. Besides, these findings showed that there are relationships between inflammation-related gene polymorphism and the number of depressive episodes along with the history of atypical depression in patients diagnosed with $\mathrm{BD}$. Confirming the present results with other inflammation-related gene polymorphisms in other populations covering larger regions will better explain the role of inflammation in the pathogenesis of SCZ and BD.

Acknowledgment. The authors gratefully acknowledge Cambridge Proofreading LLC for native English editing.

\section{References}

1. Avramopoulos D, Pearce BD, McGrath J, Wolyniec P, Wang R, Eckart $\mathrm{N}$, et al. Infection and inflammation in schizophrenia and bipolar disorder: a genome wide study for interactions with genetic variation. PloS one 2015; 10: e0116696.

2. Consortium SWGotPG. Biological insights from 108 schizophrenia-associated genetic loci. Nature 2014; 511: 421-427.

3. Sklar P, Ripke S, Scott LJ, Andreassen OA, Cichon S, Craddock $\mathrm{N}$, et al. Large-scale genome-wide association analysis of bipolar disorder identifies a new susceptibility locus near ODZ4. Nature genetics 2011; 43: 977.

4. Aytac HM, Oyaci Y, Pehlivan M, Pehlivan S. DNA Methylation Pattern of Gene Promoters of MB-COMT, DRD2, and NR3C1 in Turkish Patients Diagnosed with Schizophrenia. Clinical Psychopharmacology and Neuroscience 2021.

5. Markota M, Coombes BJ, Larrabee BR, McElroy SL, Bond DJ, Veldic M, et al. Association of schizophrenia polygenic risk score with manic and depressive psychosis in bipolar disorder. Transl Psychiatry 2018; 8: 1-7.

6. Erkmen T, Şahin C, Arıcıŏglu F. Şizofreni'de İnflamatuvar Mekanizmaların Yeri. Journal of Marmara University Institute of Health Sciences 2015; 5: 134-139.

7. Fineberg AM, Ellman LM. Inflammatory cytokines and neurological and neurocognitive alterations in the course of schizophrenia. Biol Psychiatry 2013; 73: 951-966.

8. Aytac HM, Pehlivan S. Viral Pandemics as Possible Psychoimmunological Causes of Psychiatric Symptoms: From Past to Present. Journal of Advanced Research in Health Sciences 2020; 3: 92-98.

9. Muneer A. Bipolar disorder: role of inflammation and the development of disease biomarkers. Psychiatry Investig 2016; 13: 18-33.

10. Moens L, Van Hoeyveld E, Peetermans WE, De Boeck C, Verhaegen J, Bossuyt X. Mannose-binding lectin genotype and invasive pneumococcal infection. Hum Immunol 2006; 67: 605-611.

11. Onay H, Pehlivan M, Alper S, Ozkinay F, Pehlivan S. Might there be a link between mannose binding lectin and vitiligo? Eur J Dermatol 2007; 17: 146-148.

12. Gadjeva M, Takahashi K, Thiel S. Mannan-binding lectin--a soluble pattern recognition molecule. Mol Immunol 2004; 41: 113-121. 
13. Miller C, Wilgenbusch S, Michael M, Chi DS, Youngberg G, Krishnaswamy G. Molecular defects in the mannose binding lectin pathway in dermatological disease: Case report and literature review. Clin Mol Allergy 2010; 8: 6.

14. Jensenius J. Mannan-binding lectin deficiency is associated with unexplained recurrent miscarriage. Scand J Immunol 1999; 49: 193-196.

15. Koucký M, Maličková K, Kopřivová H, Cindrová-Davies T, Hrbáčková H, Černý A, et al. Low maternal serum concentrations of mannose-binding lectin are associated with the risk of shorter duration of pregnancy and lower birthweight. Scandinavian journal of immunology 2018; 88: e12675.

16. Pagowska-Klimek I, Cedzyński M. Mannan-binding lectin in cardiovascular disease. BioMed research international 2014; 2014.

17. De Pascale G, Cutuli SL, Pennisi MA, Antonelli M. The role of mannose-binding lectin in severe sepsis and septic shock. Mediators Inflamm 2013; 2013: 625803.

18. Tsutsumi A, Takahashi R, Sumida T. Mannose binding lectin: genetics and autoimmune disease. Autoimmunity reviews 2005; 4: 364-372.

19. Association WM. World Medical Association Declaration of Helsinki: ethical principles for medical research involving human subjects. JAMA 2013; 310: 2191-2194.

20. First MB, Spitzer RL, Gibbon M, Williams JB. User's guide for the Structured clinical interview for DSM-IV axis I disorders SCID-I: clinician version: American Psychiatric Pub; 1997.

21. Çorapçıŏlu A, Aydemir Ö, Yıldız M, Esen A, Köroğlu E. DSM-IV Eksen I Bozuklukları (SCID-I) için yapılandırılmış klinik görüşme, klinik versiyon. Ankara: Hekimler yayın birliği. 1999.

22. Aytac HM, Ozdilli K, Tuncel FC, Pehlivan M, Pehlivan S. Tumor Necrosis Factor-alpha (TNF- $\alpha$ ) -238 G/A Polymorphism Is Associated with the Treatment Resistance and Attempted Suicide in Schizophrenia. Immunol Invest 2020; 1-13.

23. Karadağ F, Oral ET, Aran Yalçın F, Erten E. Young mani derecelendirme ölçeğinin Türkiye'de geçerlik ve güvenilirliği. Türk Psikiyatri Dergisi 2001; 13: 107-114.

24. Hamilton M. A rating scale for depression. J Neurol Neurosurg Psychiatry1960; 23: 56-62.

25. Akdemir A, Örsel S, Dağ İ, Türkçapar H, İşcan N, Özbay H. Hamilton Depresyon Derecelendirme Ölçeği (HDDÖ)'nin geçerliği, güvenirliği ve klinikte kullanımı. Psikiyatri Psikoloji Psikofarmakoloji Dergisi 1996; 4: 251-259.

26. Kay SR, Fiszbein A, Opler LA. The positive and negative syndrome scale (PANSS) for schizophrenia. Schizophr Bull 1987; 13: 261-276.

27. Kostakoğlu A, Batur S, Tiryaki A, Göğüş A. Pozitif ve negatif sendrom ölçeğinin (PANSS) Türkçe uyarlamasının geçerlilik ve güvenilirliği. Türk Psikoloji Dergisi 1999; 14: 23-32.

28. Guy W, editor. ECDEU Assessment Manual for Psychopharmacology. 1976. Rockville, MD (USA). Department of Health, Education, and Welfare.

29. David AS. Insight and psychosis. Br J Psychiatry 1990; 156: 798-808.

30. Arslan S GKB, Karakılıç H. İçgörünün üç bileşenini değerlendirme ölçeği:güvenilirlik ve geçerlik çalışması. Türkiye'de Psikiyatri 2001; 3: 17-24.

31. Conley RR, Kelly DL. Management of treatment resistance in schizophrenia. Biol Psychiatry 2001; 50: 898-911.

32. Binbay Z, Solmaz M, Kurt E. Tedaviye Dirençli İki Uçlu Bozukluk. Journal of Mood Disorders 2015; 5.
33. Gao S, Lu S, Shi X, Ming Y, Xiao C, Sun J, et al. Distingushing between treatment-resistant and non-treatment-resistant schizophrenia using regional homogeneity. Front Psychiatry 2018; 9: 282.

34. Sachs GS. Treatment-resistant bipolar depression. Psychiatr Clin North Am 1996; 19: 215-236.

35. Baysal E, Oguzkan-Balci S, Tunc O, Celenk F, Deniz M, Kanlikama M, et al. The polymorphisms of the MBL2 and MIF genes associated with Pediatric Cochlear Implant Patients. Int J Pediatr Otorhinolaryngol 2013; 77: 338-340.

36. Lee WC, Wang LY. Simple formulas for gauging the potential impacts of population stratification bias. Am J Epidemiol 2008; 167: 86-89.

37. Steffensen R, Thiel S, Varming K, Jersild C, Jensenius JC. Detection of structural gene mutations and promoter polymorphisms in the mannan-binding lectin (MBL) gene by polymerase chain reaction with sequence-specific primers. $J$ Immunol Methods 2000; 241: 33-42.

38. Lipscombe R, Sumiya M, Summerfield J, Turner M. Distinct physicochemical characteristics of human mannose binding protein expressed by individuals of differing genotype. Immunology 1995; 85: 660-667.

39. Madsen HO, Garred P, Thiel S, Kurtzhals J, Lamm LU, Ryder LP, et al. Interplay between promoter and structural gene variants control basal serum level of mannan-binding protein. $J$ Immunol 1995; 155: 3013-3020.

40. Erol N, Kılıç C, Ulusoy M, Kececi M. Mental health profile in Turkey: a main report. Turkish Republic, Ministry of Health, Ankara. 1998: 77-93.

41. Mayilyan KR, Arnold JN, Presanis JS, Soghoyan AF, Sim RB. Increased complement classical and mannan-binding lectin pathway activities in schizophrenia. Neurosci Lett 2006; 404: 336-341.

42. Foldager L, Steffensen R, Thiel S, Als TD, Nielsen HJ, Nordentoft M, et al. MBL and MASP-2 concentrations in serum and $M B L 2$ promoter polymorphisms are associated to schizophrenia. Acta Neuropsychiatr 2012; 24: 199-207.

43. Aytac HM, Oyaci Y, Yazar MS, Erol A, Pehlivan S. Association of MIF and MBL2 gene polymorphisms with attempted suicide in patients diagnosed with schizophrenia or bipolar disorder. $J$ Clin Neurosci 2020; 78: 264-268.

44. Aytac HM, Oyaci Y, Yazar MS, Pehlivan S. Macrophage Migration Inhibitory Factor - 173 G/C Polymorphism is Associated With The Age of Onset and Insight in Schizophrenia in the Turkish Population. Neurol Res 2021; 1-8.

45. Sekar A, Bialas AR, de Rivera H, Davis A, Hammond TR, Kamitaki N, et al. Schizophrenia risk from complex variation of complement component 4. Nature 2016; 530: 177-183.

46. Foldager L, Kohler O, Steffensen R, Thiel S, Kristensen AS, Jensenius JC, et al. Bipolar and panic disorders may be associated with hereditary defects in the innate immune system. J Affect Disord 2014; 164: 148-154.

47. Reginia A, Kucharska-Mazur J, Jabłoński M, Budkowska M, Dołtegowska B, Sagan L, et al. Assessment of complement cascade components in patients with bipolar disorder. Front Psychiatry 2018; 9: 614.

48. Li WJ, Kou CG, Yu Y, Sun S, Zhang X, Kosten TR, et al. Association of catechol-O-methyltransferase gene polymorphisms with schizophrenia and negative symptoms in a Chinese population. Am J Med Genet B Neuropsychiatr Genet 2012; 159B: 370-375. 
49. Lahdelma L, Ahokas A, Andersson LC, Suvisaari J, Hovatta I, Huttunen MO, et al. Human leukocyte antigen-A1 predicts a good therapeutic response to clozapine with a low risk of agranulocytosis in patients with schizophrenia. J Clin Psychopharmacol 2001; 21: 4-7.

50. Lahdelma L, Koskimies S. Impact of HLA haplotype on the response to antipsychotic treatment of schizophrenia. Current Pharmacogenomics 2004; 2: 149-155.

51. Drago A, Giegling I, Schafer M, Hartmann AM, Konte B, Friedl $\mathrm{M}$, et al. Genome-wide association study supports the role of the immunological system and of the neurodevelopmental processes in response to haloperidol treatment. Pharmacogenet Genomics 2014; 24: 314-319.

52. Geoffroy PA, Bellivier F, Leboyer M, Etain B. Can the response to mood stabilizers be predicted in bipolar disorder? Front Biosci (Elite Ed) 2014; 6: 120-138.

53. Rybakowski JK, Czerski P, Dmitrzak-Weglarz M, Kliwicki S, Leszczynska-Rodziewicz A, Permoda-Osip A, et al. Clinical and pathogenic aspects of candidate genes for lithium prophylactic efficacy. J Psychopharmacol 2012; 26: 368-373.

54. Panaccione I, Spalletta G, Sani G. Neuroinflammation and excitatory symptoms in bipolar disorder. Neuroimmunol Neuroinflammation 2015; 2: 215-227.

55. Bosetti F, Weerasinghe GR, Rosenberger TA, Rapoport SI. Valproic acid down-regulates the conversion of arachidonic acid to eicosanoids via cyclooxygenase- 1 and -2 in rat brain. $J$ Neurochem 2003; 85: 690-696.

56. Akcan U, Karabulut S, Küçükali Cİ, Çakır S, Tüzün E. Bipolar disorder patients display reduced serum complement levels and elevated peripheral blood complement expression levels. Acta Neuropsychiatr 2018; 30: 70-78.
57. Gouvea E, Ota V, Noto C, Santoro M, Spindola L, Moretti P, et al. Gene expression alterations related to mania and psychosis in peripheral blood of patients with a first episode of psychosis. Transl Psychiatry 2016; 6: e908.

58. Bolu A, Erdem M, Balikci A, Bilgen AE, Akgül EO, Uzun O, et al. The relationship between serum levels of haptoglobin and neopterin and the number of episodes in patients with major depression. Journal of Mood Disorders 2013; 3: 1.

59. Moylan S, Maes M, Wray NR, Berk M. The neuroprogressive nature of major depressive disorder: pathways to disease evolution and resistance, and therapeutic implications. Mol Psychiatry 2013; 18: 595-606.

60. Lamers F, Milaneschi Y, de Jonge P, Giltay EJ, Penninx B. Metabolic and inflammatory markers: associations with individual depressive symptoms. Psychol Med 2018; 48: 11021110.

61. Lamers F, Vogelzangs N, Merikangas KR, de Jonge P, Beekman AT, Penninx BW. Evidence for a differential role of HPA-axis function, inflammation and metabolic syndrome in melancholic versus atypical depression. Mol Psychiatry 2013; 18: 692-699.

62. Lasserre AM, Glaus J, Vandeleur CL, Marques-Vidal P, Vaucher J, Bastardot F, et al. Depression with atypical features and increase in obesity, body mass index, waist circumference, and fat mass: a prospective, population-based study. JAMA Psychiatry 2014; 71: 880-888.

\section{Copyright}

Whenever a manuscript contains material (tables, figures, etc.) which is protected by copyright (previously published), it is the obligation of the author to obtain written permission from the holder of the copyright (usually the publisher) to reproduce the material in Saudi Medical Journal. This also applies if the material is the authors own work. Please submit copies of the material from the source in which it was first published. 